Pendas : Jurnal IImiah Pendidikan Dasar, ISSN Cetak : 2477-2143 ISSN Online : 2548-6950

Volume V Nomor 02, Desember 2020

\title{
PENERAPAN MODEL CONTEXTUAL TEACHING AND LEARNING BERBANTUAN MEDIA POP-UP BOOK UNTUK MENINGKATKAN AKTIVITAS SISWA SD
}

\author{
Anis Zulfatin Nihayah ${ }^{1}$, Fina Fakhriyah², Much. Arsyad Fardani ${ }^{3}$ \\ ${ }^{123}$ PGSD FKIP Universitas Muria Kudus \\ 1aniszulfatin7@gmail.com, 2fina.fakhriyah@umk.ac.id, \\ 3arsyad.fardhani@umk.ac.id
}

\begin{abstract}
This study aims to determine the increase in student activity by applying the contextual teaching and learning model aided by pop-up media. This research was conducted in grade $V$ elementary school with the number of students 26 . The method used is a classroom action research method that lasted for 2 cycles, each cycle consisting of planning, implementation, observation, and reflection. Data collection techniques used were interviews, observation, tests, and documentation. Analysis of the data used is quantitative data analysis and qualitative data analysis. the results of observations in cycle I get an average percentage of $68.07 \%$ with qualifications need guidance, and in cycle II increased to $84 \%$ with good qualifications. From the research that has been done it can be concluded that the contextual teaching and learning model is assisted Pop-up book media can increase student activity.
\end{abstract}

Keywords: Student Activity, CTL, Pop-Up Book

\section{ABSTRAK}

Penelitian ini bertujuan untuk mengetahui peningkatan aktivitas siswa dengan diterapkannya model contextual teaching and learning berbantuan media pop up book. Penelitian ini dilaksanakan di kelas V SD dengan jumlah siswa 26. Metode yang digunakan yakni metode penelitian tindakan kelas yang berlangsung selama 2 siklus, masing-masing siklus terdiri dari atas perencanaan, pelaksanaan, observasi, dan refleksi. Teknik pengumpulan data yang digunakan yaitu wawancara, observasi, tes, dan dokumentasi. Analisis data yang digunakan yaitu analisis data kuantitatif dan analisis data kualitatif. hasil dari observasi pada siklus I mendapatkan hasil rata-rata persentase berjumlah 68,07\% dengan kualifikasi perlu bimbingan, dan pada siklus II meningkat menjadi 84\% dengan kualifikasi baik.. Dari penelitian yang telah dilakukan dapat disimpulkan bahwa model pembelajaran contextual teaching and learning berbantuan media pop-up book dapat meningkatkan aktivitas siswa.

Kata kunci: Aktivitas Siswa, CTL, Pop-Up Book 
Pendas : Jurnal IImiah Pendidikan Dasar, ISSN Cetak : 2477-2143 ISSN Online : 2548-6950 Volume V Nomor 02, Desember 2020

\section{A. Pendahuluan}

Salah satu sekolah dasar yang berada di Kabupaten Kudus khususnya kelas $\mathrm{V}$, pada saat proses pembelajaran aktivitas siswa dalam mengikuti kegiatan belajar masih rendah. Hal ini dibuktikan dari hasil observasi aktivitas belajar siswa pada prasiklus mendapatkan rata-rata 49 dengan kriteria perlu bimbingan. ada 8 indikator aktivitas siswa pada lembar observasi prasiklus yaitu Visual Activities, Oral Activities, Listening Activitie, Writing Activitie, Drawing Activities, Motor Activities, Mental Activitie, Emotional Activities. delapan indikator tersebut siswa belum berani mengungkapkan pendapatnya dan kurang aktif dalam mengikuti pembelajaran.

Berdasarkan pada temuan tersebut, dapat diketahui bahwa aktivitas belajar siswa masih kurang maksimal. Kurang aktifnya siswa dalam bekerjasama saat kegiatan diskusi disebabkan karena proses pembelajaran yang diterapkan guru tidak mengajak siswa untuk memahami konsep materi pembelajaran secara lansung melalui proses percobaan atau praktik. Hal ini mengakibatkan dalam proses pembelajaran siswa tidak memperhatikan penjelasan guru dan mengikuti kegiatan belajar dengan baik.

Hasil observasi awal dan wawancara dengan guru kelas $\mathrm{V}$, dijelaskan bahwa kurangnya aktivitas belajar siswa dalam mengikuti proses pembelajaran, dikarenakan ada beberapa siswa yang tidak berani untuk menyampaikan pendapatnya, pada saat penyampaian materi pembelajaran guru tidak mengajak siswa untuk aktif mengikuti kegiatan belajar dan pada saat kegiatan pembelajaran sedang berlangsung ada beberapa siswa yang tidak mengikuti kegiatan belajar dengan sungguh-sungguh, hal itu menyebabkan rendahnya aktivitas belajar siswa, dikarenakan siswa tidak berani menyampaikan pendapatnya yang nantinya pendapat tesebut disalahkan oleh siswa lain ataupun guru.

Aktivitas belajar Menurut (Sardiman, 2016) yaitu prinsip belajar yakni berbuat. Berbuat mengubah tingkah laku, jadi melakukan kegiatan atau sesuatu. Tidak ada belajar kalau tidak ada aktivitas. Itulah sebabnya aktiitas merupakan prinsip atau asas yang sangat penting di dalam interaksi belajar mengajar. 
Pendas : Jurnal IImiah Pendidikan Dasar, ISSN Cetak : 2477-2143 ISSN Online : 2548-6950 Volume V Nomor 02, Desember 2020

Diedrich dalam (Sardiman, 2016) membuat suatu daftar yang berisi kegiatan siswa yang anatara lain dapat digolongkan sebagai berikut: 1) Visual activities, yang termasuk di dalamnya misalnya: membaca, memperhatikan gambar demontrasi, percobaan, pekerjaan orang lain, 2) Oral activities, seperti menyatakan, merumuskan,bertanya, memberi saran, mengeluarkan pendapat, mengadakan wawancara, diskusi, interupsi, 3) Listening activities, sebagai contoh mendengarkan: uraian, percakapan, diskusi, musik, pidato, 4) Writing activities, seperti misalnya: menulis cerita, karangan, laporan angket, menyalin, 5) Drwaing activities ,misalnya menggambar, membuat grafik, peta, diagram, 6) Motor activities, yang termasuk di dalamnya antara lain: melakukan percobaan, membuat konstruksi, model mereparasi, bermain, berkebun, beternak, 7) Mental activities, sebagai contoh misalnya: menanggapi, mengingat, memecahkan soal, menganalisis, melihat hubungan, mengambil keputusan, 8) Emotional activities, seperti misalnya:menaruh minat, merasa bosan, gembira, bersemangat, bergairah, berani, tenang, gugup.

Penerapan model pembelajaran dalam proses pembelajaran dapat menciptakan suasana yang membuat siswa merasa senang dan berani mengungkapkan pendapatnya, serta dapat meningkatkan aktivitas belajar siswa.

Model pembelajaran dapat diterapkan agar siswa aktif dalam mengikuti proses pembelajaran, salah satunya yakni model pembelajaran Contextual Teaching and Learning (CTL). Model pembelajaran Contextual Teaching and Learning (CTL) merupakan suatu model pembelajaran yang mengharuskan guru menghubungkan materi dengan kehiduan sehari-hari siswa. Model CTL merupakan konsep belajar yang membantu guru mengaitkan antara materi yang diajarkannya dengan situasi dunia nyata siswa dan mendorong siswa membuat hubungan antara pengetahuan yang dimilikinya dengan penerapannya dalam kehidupan mereka sebagai anggota keluarga dan masyarakat (Hadiyanta, 2013).

Model pembelajaran Contextual Teaching and Learning merupakan model pembelajaran yang mana guru 
Pendas : Jurnal IImiah Pendidikan Dasar, ISSN Cetak : 2477-2143 ISSN Online : 2548-6950 Volume V Nomor 02, Desember 2020

dapat mengaitkan materi yang disampaikan dengan kehidupan sehari-hari siswa (Rahmawati, 2018)

Model pembelajaran CTL menurut (Shoimin, 2017) adalah suatu proses pembelajaran yang holistik dan bertujuan dapat memberikan motivasi siswa untuk memahami arti materi yang dipelajarinya dengan menghubungkan materi tersebut pada konteks kehidupan sehari-hari, sehingga siswa memiliki pengetahuan atau keterampilan secara fleksibel dapat diterapkan dari satu permasalahan ke permasalahan lainnya. (Hamdayama, 2014) menjelaskan bahwa model pembelajaran CTL adalah konsep belajar yang dapat membantu guru untuk menghubungkan materi yang diajarkan dengan situasi dunia nyata siswa, sehingga dapat mendorong siswa untuk membuat hubungan antara pengetahuan yang sudah dimilikinya dengan penerapannya dalam kehidupan mereka sebagai anggota keluarga maupun masyarakat.

(Mellinda, D., Jayadinata, A. K., \& Gusrayani, 2017) mengemukakan bahwa model pembelajaran CTL adalah model pembelajaran yang mengharuskan siswa untuk aktif dalam

mengikuti

proses pembelajaran, dan siswa juga dituntut untuk menemukan pengetahuan secara mandiri dengan cara menghubungkan pengetahuan yang sudah dimilikinya dengan kehidupan sehari-hari. Sedangkan (Handini, 2016) mengemukakan bahwa model pembelajaran CTL merupakan suatu rancangan pembelajaran yang dilakukan dengan melibatkan materi pembelajaran pada dunia nyata dan pengalaman yang dialami oleh peserta didik.

Model pembelajaran CTL mempunyai tujuan yakni memberikan pemahaman arti atau makna materi yang sudah dijelaskan oleh guru, sehingga siswa dapat mengaitkan pengetahuan yang sudah dimilikinya dengan kehidupan sehari-hari, siswa juga ditekankan memiliki pengetahuan serta keterampilan secara dinamis dan fleksibel untuk menghubungkan secara mandiri pengetahuannya dengan kehidupan sehari-hari.

Tahapan model pembelajaran CTL menurut (Rahmawati, 2018) sebagai berikut: (1) Guru memberikan materi untuk dipelajari sendiri oleh siswa, (2) Dengan bimbingan guru siswa saling bertanya jawab dengan teman satu kelompoknya, 
Pendas : Jurnal IImiah Pendidikan Dasar, ISSN Cetak : 2477-2143 ISSN Online : 2548-6950 Volume V Nomor 02, Desember 2020

Bersama kelompoknya siswa mencari pengetahuan baru dengan memecahkan masalah yang diberikan oleh guru, (4) Siswa saling bekerjasama dalam diskusi kelompok, (5) Perwakilan setiap kelompok mempresentasikan hasil kerja kelompoknya di depan kelas, (6) Siswa menanggapi hasil diskusi kelompok yang mempresentasikan hasil kerja kelompoknya, (7) Siswa bersama guru mengingat kegiatan yang sudah dilakukan dan membuat kesimpulan materi mengenai materi yang sudah dipelajari, (8) Guru melaksanakan evaluasi secara mandiri.

Penelitian yang sudah dilakukan oleh (Astuti, Y., Mustaji, 2015) menunjukkan bahwa penerapan model pembelajaran CTL dapat meningkatkan aktivitas siswa. Hal tersebut dibuktikan dengan peningkatan persentase pencapaian pada siklus I yaitu $75,36 \%$ meningkat pada siklus II menjadi $82,09 \%$, dan meningkat pada siklus III menjadi $87,83 \%$. Penelitian tersebut dikatakan berhasil dikarenakan penerapan model CTL dapat meningkatkan aktivitas belajar.

Proses pembelajaran dapat berjalan dengan baik apabila penerapan model pembelajaran juga didukung dengan media pembelajaran yang sesuai dengan materi dan kebutuhan siswa, seperti dalam media terdapat berbagai permasalahan secara nyata dan dapat merangsang siswa untuk aktif mengikuti proses pembelajaran. Media yang digunakan dalam penelitian ini yakni media PopUp Book. Menurut (Sylvia, 2015), Pop-Up Book merupakan sebuah buku yang dapat bergerak ketika halamannya dibuka dan memiliki tampilan gambar yang indah, serta dapat ditegakkan dan memiliki unsur 3 dimensi.

(Dianita, 2017) menjelaskan bahwa media Pop-Up Book yakni media pembelajaran yang timbul dan terdiri dari gambaran yang telah diketahui dapat meningkatkan daya serap dan kemampuan mengingat siswa mengenai materi pembelajaran yang disampaikan oleh guru. Pop-Up Book merupakan media pembelajaran yang memiliki gaya 3 dimensi berbentuk buku dan apabila dibuka dapat memberikan kesan yang menakjubkan (Wati, 2017).

(Rizkiyah, 2019), yaitu terdapat bahwa dengan menggunakan media Pop-Up Book dapat memberikan visualisasi yang unik, menarik serta 
Pendas : Jurnal IImiah Pendidikan Dasar, ISSN Cetak : 2477-2143 ISSN Online : 2548-6950 Volume V Nomor 02, Desember 2020

dapat bergerak ketika halamannya dibuka, sehingga Pop-Up Book sangatlah cocok untuk siswa sekolah dasar karena memberikan kesan yang jauh lebih menyenangkan dalam proses pembelajaran. Media tersebut memberikan visualisasi cerita atau informasi yang lebih menarik melalui tampilan gambar yang membentuk 3 dimensi dan dapat menarik perhatian siswa dalam memahami materi pembelajaran (Rengganis, 2017).

(Dewanti, Handaruni, 2018) melakukan penelitian mengenai media Pop-Up Book, yang menunjukkan bahwa berdasarkan dari hasil validasi media kepada validator dieroleh persentase $95,71 \%$ dari validasi ahli media, dari ahli materi memperoleh persentase sebesar $94,93 \%$, dan dari ahli pengguna (guru) memperoleh persentase sebesar 95,20\% dengan kriteria sangat valid, sehingga media Pop-Up Book sangat layak untuk digunakan dalam proses pembelajaran.

Media Pop-Up Book ini dapat melibatkan siswa secara langsung dalam pembelajaran sehingga dengan cara kreatif dapat melakukan percobaan dan menemukan sumber energi panas, dan perpindahan panas secara konduksi maupun secara konveksi. Penerapan model CTL dengan berbantuan media Pop-Up Book diharapkan dapat menarik perhatian siswa dan dapat memfokuskan tujuan pembelajaran. Pada proses pembelajaran dengan menerapkan model CTL berbantuan media Pop-Up Book siswa dituntut untuk memahami materi yang dijelaskan mengunakan media pembelajaran tersebut, setelah siswa memahami materi yang telah disampaikan kemudian siswa melakukan kegiatan percobaan untuk membuktikan mengenai materi yang telah disampaikan oleh guru.

Penelitian ini mengunakan media Pop-Up Book yang berbentuk buku dan berisi materi mengenai sumber energi, suhu dan panas, perpindahan panas secara konduksi dan perpindahan panas secara konveksi.

Berdasarkan uraian tersebut, maka peneliti melakukan tindakan dengan tujuan penerapan model Contextual Teaching and Learning berbantuan media Pop-Up Book untuk meningkatkan aktivitas belajar siswa kelas V SD pada tema 6 "Panas dan Perpindahannya".

\section{B. Metode Penelitian}

Penelitian ini termasuk dalam penelitian tindakan kelas yang 
Pendas : Jurnal Ilmiah Pendidikan Dasar, ISSN Cetak : 2477-2143 ISSN Online : 2548-6950 Volume V Nomor 02, Desember 2020

mengacu pada model yang dikemukakan oleh Kemmis dan Mc. Taggart. Penelitian ini dilaksanakan dalam dua siklus yakni siklus I dan siklus II. Pada setiap siklus dilakukan dalam dua pertemuan. Setiap siklus meliputi 4 tahapan yaitu perencanaan, pelaksanaan,observasi, dan refleksi.

Penelitian tindakan kelas ini dilaksanakan di SD, subjek penelitian ini adalah siswa kelas $V$ SD yang berumlah 26 siswa. Teknik pengumpulan data yang digunakan dalam penelitian tindakan kelas ini yaitu wawancara, observasi, tes, dan dokumentasi. Instrumen yang digunakan dalam penelitian ini yaitu instrumen lembar observasi dan pedoman wawancara.

Indikator keberhasilan pada penelitian ini adalah sebagai berikut: peningkatan aktivitas belajar siswa dalam tema bagian 6 "Panas dan Perpindahannya" yaitu dengan menerapkan model pembelajaran Contextual Teaching Learning berbantuan media Pop-Up Book meningkat dengan penilaian $\geq 75 \%$ dengan kriteria penilaian baik atau aktif, sebagai berikut: peningkatan aktivitas belajar siswa dalam tema 6 "Panas dan Perpindahannya".
C.Hasil Penelitian dan Pembahasan

Penelitian tindakan kelas ini berlangsung selama 2 siklus yakni siklus I dan siklus II, pada setiap siklusnya terdiri dari 2 pertemuan. Pada setiap kegiatan pembelajaran dilaksanakan observasi atau pengamatan untuk mengetahui peningkatan aktivitas belajar pada tema 6 "Panas dan Perpindahannya" yang dimiliki siswa kelas $\mathrm{V}$ SD. Berdasarkan hasil observasi yang dilakukan, diperoleh bahwa hasil nilai rata-rata siklus I yakni 68 dengan kriteria perlu bimbingan. Berikut ini merupakan hasil observasi aktivitas belajar yang dapat dilihat pada Tabel 1 sebagai berikut:

Tabel 1 Rekapitulasi Lembar Observasi Aktivitas Belajar Siswa

\begin{tabular}{|c|c|c|c|}
\hline No. & Indikator & Siklus I & $\underset{\text { II }}{\text { Siklus }}$ \\
\hline 1. & Visual Activities & 69 & 92 \\
\hline 2. & Oral Activities & 57 & 76 \\
\hline 3. & $\begin{array}{l}\text { Listening } \\
\text { Activities }\end{array}$ & 71 & 83 \\
\hline 4. & Writing Activities & 62 & 78 \\
\hline 5. & $\begin{array}{l}\text { Drawing } \\
\text { Activities }\end{array}$ & 66 & 81 \\
\hline 6. & Motor Activities & 76 & 94 \\
\hline 7. & Mental Activities & 69 & 85 \\
\hline 8. & $\begin{array}{l}\text { Emotional } \\
\text { Activities }\end{array}$ & 76 & 87 \\
\hline & Jumlah & 546 & 676 \\
\hline & Rata-Rata & 68, & 85 \\
\hline & Persentase & $68 \%$ & $85 \%$ \\
\hline & Kriteria & $\begin{array}{c}\text { Perlu } \\
\text { Bimbingan }\end{array}$ & Baik \\
\hline
\end{tabular}

Data yang diperoleh dari tabel 1 diketahui terjadi penigkatan 
Pendas : Jurnal IImiah Pendidikan Dasar, ISSN Cetak : 2477-2143 ISSN Online : 2548-6950 Volume V Nomor 02, Desember 2020

persentase skor pada siklus I ke siklus Il yakni sebesar 17\%. Hasil dari setiap indikator aktivitas belajar siswa mengalami kenaikan, indikator pertama visual activities pada siklus I mendapatkan rata-rata 69 sedangkan pada siklus II mendapatkan rata-rata 92, indikator kedua oral activities pada siklus I mendapatkan skor 57 dan siklus II mendapatkan skor 76, indikator ketiga listening activities pada siklus I mendapatkan rata-rata sebesar 71 dan siklus II mendapatkan rata-rata sebesar 83.

Indikator keempat yaitu writing activities pada siklus I mendapatkan rata-rata 62 dan siklus II mendapatkan rata-rata sebesar 78, indikator kelima yakni drawing activities pada siklus I mendapatkan rata-rata sebesar 66 dan pada siklus II mendapatkan ratarata sebesar 94, indikator keenam yakni motor activities pada siklus I mendapatkan rata-rata sebesar76 dan pada siklus II mendapatkan rata-rata sebesar 94, indikator ketujuh yakni mental activities pada siklus I mendapatkan rata-rata sebesar 69 dan pada siklus II mendapatkan ratarata sebesar 85 , indikator kedelapan yakni emotional activities pada siklus I mendapatkan rata-rata sebesar 76 , dan pada siklus II mendapatkan ratarata sebesar 87.

Penerapan model pembelajaran CTL pada penelitian ini terdapat langkah-langkah yang dapat mempengaruhi keberhasilan dalam pembelajaran dengan penerapan model CTL diantaranya yaitu: 1) Siswa memperhatikan media Pop Up yang sudah disiapkan oleh guru, dan guru menyampaikan materi pembelajaran dengan menggunakan media pop-up book, 2) Guru membagi lembar kerja siswa dan menjelaskan mengenai permasalahan yang harus didisusikan oleh siswa dengan kelompoknya,

Siswa memperhatikan sumber-sumber energi panas apa saja yang mereka gunakan sehari-hari dari pagi hingga malam, 4) Siswa melakukan percobaan sumber energi panas matahari, 5) Siswa mengamati hasil percobaan dan menjawab pertanyaan-pertanyaan yang berkaitan dengan percobaan, 6) perwakilan setiap kelompok mempresentasikan hasil diskusinya di depan kelas, 7) siswa bersama guru menyimpulkan materi yang telah dipelajari.

Pada saat berdiskusi, siswa berdiskusi dan mengungkapkan 
Pendas : Jurnal IImiah Pendidikan Dasar, ISSN Cetak : 2477-2143 ISSN Online : 2548-6950 Volume V Nomor 02, Desember 2020

pendapat mengenai jawaban dari soal yang berkaitan dengan percobaan yang telah dilakukan, hal tersebut membuat siswa berani mengungkapkan pendapat pada saat berdiskusi. Dari hasil observasi aktivitas belajar siswa dari siklus I ke siklus II pada pembelajaran tema 6 panas dan perpindahanya dengan menerapkan model contextual teaching and learning berbantuan media pop up book pada kelas V SD menunjukkan adanya peningkatan.

Peningkatan hasil observasi aktivitas belajar siswa dapat dilihat pada peningkatan hasil observasi pada siklus I dan siklus II. Hasil observasi aktivitas belajar siswa siklus I pertemuan I diperoleh total skor 1674 dan skor rata-rata 64,38 dengan kriteria perlu bimbingan, sedangkan pada siklus I pertemuan II diperoleh skor 1866 dan skor rata-rata 72 dengan kriteria cukup. Hasil observasi aktivitas belajar siswa pada siklus II pertemuan I diperoleh total skor 2070 dengan rata-rata 80 dengan kriteria baik, sedangkan pada pelaksanaan siklus II pertemuan II diperoleh total skor 2258 dan skor rata-rata 87 dengan kriteria baik.

Berdasarkan hasil observasi pada siklus I dan siklus II, maka diperoleh rata-rata sebesar 68,07 dengan kriteria perlu bimbingan dan rata-rata pada siklus II sebesar 85 dengan kriteria baik. Demikian penelitian tindakan kelas dengan menerapkan model contextual teaching and learning berbantuan media pop up book pada siswa kelas V SD sudah dikatakan berhasil karena keterampilan mengajar guru sudah mencapai indikator keberhasilan yang diinginkan oleh peneliti yakni $\geq 75 \%$ dengan kriteria baik.

Peneliti juga menemukan peningkatan aktivitas siswa dikarenakan siswa sunggguhsungguh dalam memperhatikan penjelasan guru dan mengajukan pertanyaan yang berkaitan dengan materi pembelajaran, siswa juga melakukan diskusi dan melakukan percobaan sederhana sesuai dengan arahan guru, selain itu siswa berani mengungkapkan pendapatnya pada saat berdiskusi dan berani menanggapi teman pada saat kegiatan presentasi. Hal tersebut sependapat dengan (Elida, 2012) yang menyatakan bahwa aktivitas berpikir, berbicara, dan menulis adalah salah satu bentuk aktivitas belajar-mengajar yang memberikan 
Pendas : Jurnal IImiah Pendidikan Dasar, ISSN Cetak : 2477-2143 ISSN Online : 2548-6950 Volume V Nomor 02, Desember 2020

peluang kepada siswa untuk berpartisipasi aktif.

Penelitian yang sudah dilakukan oleh (Kurniawan. D.A, 2015) membuktikan bahwa penggunaan model pembelajaran CTL dapat meningkatkan aktivitas belajar PKn pada siswa kelas VI SD Negeri 4 Karangduwur Petanahan Kebumen tahun ajaran 2014/2015. Hal tersebut terbukti dengan hasil penelitian yaitu siklus I siswa menjadi lebih aktif dengan persentase rata-rata dari keseluruhan indikator adalah 65,5\%, sedangkan pada siklus II meningkat menjadi $81,8 \%$. Peningkatan aktivitas belajar ini dikatakan berhasil karena telah memenuhi indikator keberhasilan yang telah ditetapkan sebelumnya yaitu lebih dari $75 \%$.

Penelitian juga sudah dilakukan mengenai media pop- up book oleh (Dewanti, Handaruni, 2018) membuktikan bahwa Kajian produk berdasarkan hasil validasi media kepada validator, diperoleh presentase $95.71 \%$ dari validasi ahli media, 94.93\% dari ahli materi, $95.17 \%$ dari ahli pengguna (guru), dan 95\% dari uji coba pengguna (siswa). Hasil validasi secara keseluruhan yaitu $95.20 \%$ dengan kriteria "Sangat Valid", maka media ini sangat layak untuk digunakan dalam pembelajaran Tematik pada sutema Lingkungan Tempat Tinggalku.

\section{KESIMPULAN}

Berdasarkan penjelasan diatas dapat disimpulkan bahwa aktivitas belajar siswa dalam pembelajaran tema Panas dan Perpindahannya dengan penerapan model contextual teaching and learning berbantuan media pop up book mengalami peningkatan. Dibuktikan dengan adanya hasil observasi pada siklus I mendapatkan hasil rata-rata persentase berjumlah 68,07\% dengan kualifikasi perlu bimbingan, dan pada siklus II meningkat menjadi $84 \%$ dengan kualifikasi baik.

\section{DAFTAR PUSTAKA}

Astuti, Y., Mustaji, \& K. P. (2015). Peningkatan Aktivitas Siswa dan Hasil Belajar Siswa Melalui Pendekatan Contextual Teaching And Learning dalam Pembelajaran IPS Kelas IV A SD Bawuran Kecamatan Pleret Kabupaten Bantul. JRPD, 1(1), 20-27.

Dewanti, Handaruni, et al. (2018). Pengembangan Media Pop-Up Book Untuk Pembelajaran Lingkungan Tempat Tinggalku Kelas IV SDN 1 Pakunden Kabupaten Ponorogo. JKTP, 1(3), 221-228. 
Dianita, S. (2017). Penggunaan media pop up untuk meningkatkan hasil belajar tema ekosistem kelas $\mathrm{V}$ SDN Balong Sari I Surabaya. JPGSD, 5(1), 883-892.

Elida, N. (2012). Meningkatkan Kemampuan Komunikasi Matematik Siswa Sekolah Menengah Pertama melalui Pembelajaran Think Talk Write (TTW). Jurnal Ilmiah Program Studi Matematika, 1(2), 178-185.

Hadiyanta, N. (2013). Penerapan model contextual teaching and learning (CTL) untuk meningkatkan hasil belajar PKN. Jurnal Kependidikan, 43(1), 32-38.

Hamdayama, J. (2014). Model Pembelajaran Kreatif dan Berkarakter. Bogor: Gahlia Indonesia.

Handini, D. (2016). Penerapan model contextual teaching and learning meningkatkan hasil belajar siswa kelas IV pada materi gaya. Jurnal Pena IImiah, 1(1), 451-460.

Kurniawan. D.A. (2015). Upaya Meningkatkan Aktivitas Belajar Pendidikan Kewarganegaraan (PKN) Melalui Model Pembelajaran Contextual Teaching And Learning (CTL). Jurnal Pendidikan Ke-SDAn, 1(3), 172-175.

Mellinda, D., Jayadinata, A. K., \& Gusrayani, D. (2017). Penerapan model pembelajaran contextual teaching and learning untuk meningkatkan hasil belajar siswa kelas IV SD pada materi perubahan wujud benda. Pena IImiah, 2(1), 441-450.

Rahmawati, T. (2018). Penerapan model pembelajaran CTL untuk meningkatkan hasil belajar siswa sekolah dasar pada mata pelajaran IPA. JIPP, 2(1), 12-20.

Rengganis, M. A. N. (2017). Pengembangan media pop-up sebagai pengenalan bimbingan dan konseling komprehensif pada siswa kelas VII SMP Negeri 1 Cerme, Gresik. Jurnal BK UNESA, 7(13), 108-116.

Rizkiyah, F. L. (2019). Penggunaan media pop up book untuk meningkatkan hasil belajar IPS siswa kelas IV SDN Kajeksan Kecamatan Tulangan Kabupaten Sidoarjo. JPGSD, 7(1), 2581-2590.

Sardiman. (2016). Interaksi Dan Motivasi Belajar Mengajar. Jakarta: PT. Raja Grafido.

Shoimin, A. (2017). 68 Model Pembelajaran Inovatif dalam Kurikulum 2013. Yogyakarta: ArRuzz Media.

Sylvia, N. I. (2015). Pengaruh penggunaan media pop-up book terhadap keterampilan menulis narasi siswa sekolah dasar. JPGSD, 3(2), 1196-1205.

Wati, E. T. (2017). Pengaruh media pop-up book terhadap hasil belajar siswa tema ekosistem kelas V SDN Karangpilang 1 Surabaya. JPGSD, 5(3), 913-923. 